to $10^{\circ}$ abs. by adiabatic expansion and finally liquefies it by the Joule-Kelvin cooling. A new machine on this plan is now being constructed to work with a double cycle and deliver 6-8 litres per hour.

\section{History of American Agricultural Research}

A "History of Agricultural Experimentation in the United States, 1607-1925", by A. C. True, has just been issued as Miscellaneous Publication No. 25l by the United States Department of Agriculture, Washington, D.C. This is the third official monograph in a series intended to give a comprehensive summary of the history of agricultural education, extension and research in the United States, the two previously issued having dealt with agricultural instruction in schools and colleges, and the history of agricultural extension work respectively. The present volume naturally begins with the work of private individuals including some biographical information, and shows how they and organizations such as the geological surveys and the Patent Office, themselves little con cerned with research, laid the foundations of public agencies for agricultural investigation. It will be noted with interest that the first governmentel movement to help agriculture was made when George Washington was president, while Federal State aid for the agricultural experiment stations, founded by pioneers all over the country, was secured by Hatch in 1887 by the passage of an Act bearing his name. The rapid development of research from this period up to 1913, the effects of the Great War and the agricultural depression of 1921-25 are then described in detail. A bibliography of more than three hundred references is appended. These are limited to sources of information used in the text and to bibliographical sketches of some of the leading figures in the earlier periods of agricultural development in the United States.

\section{Marine Fauna of the Isle of Man}

The publication of a new local fauna list is always an event of some interest, and it is of importance when it concerns such historic ground as that of the sea around the Isle of Man ("Marine Fauna of the Isle of Man". Compiled by Dr. Hilary B. Moore. Editor : Dr. R. J. Daniel, assisted by J. R. Bruce and Dr. M. W. Parke. University Press of Liverpool, 1937. 2s.). This up-to-date list of the marine animals found in that region is therefore to be warmly welcomed. Future visitors to the Biological Station at Port Erin will be grateful to Dr. Moore, a former member of its staff, for his work of compilation. $\mathrm{He}$ has been wise in following the same general plan as that of the well-known "Plymouth Marine Fauna", giving after each recorded name a reference to a good description, adding notes on the ecology, and breeding dates when known. There are three charts and a general introduction describing the most accessible and typical grounds. Dr. Moore and the editors have done their work well, while the printers have succeeded in producing well-balanced and attractive pages. As a work of reference, this list will be much used; to those studying the marine ecology of our islands it will be invaluable. We should like to suggest that in future editions a note be included as to the origin of the ancient drawing of a viking ship which so attractively adorns the cover.

\section{The Film in Education}

IN "The Film in Relation to the School Curriculum" (pp. 70 ; price 1s.) the Central Information Bureau for Educational Films, Ltd., has provided a useful reprint of a series of articles which appeared in Film Progress from July 1936 until July 1937. It deals with the teaching of geography, natural history, natural science and physical training. The advice given is in close accord with the Board of Education's "Suggestions for the Consideration of Teachers", "Suggestions on Health Education" and "Science in Senior Schools", long excerpts from which are reproduced. A report to the Manchester Education Committee on experimental film-teaching is quoted in support of the assertion that children are stimulated by this means to further effort in geography and nature-study. It is claimed that their interest and mental activity are so aroused as to lead them to seek out knowledge for themselves, their powers of observation and memory are increased and, in the case of geography lessons, the film tends to eliminate anti-foreign bias. Although some teachers prefer still pictures, it seems obvious that these cannot compete with such films as "The Life-Cycle of a Plant", "The Blowfly", "The Amœba" and physical training films.

\section{Battersea Polytechnic}

IN its recently published report for 1936-37 the Battersea Polytechnic directs attention to the increased volume and high standard of its research work. In the past, this has been pursued mainly in chemistry, physics and mathematics, but new facilities have made possible extended programmes in the Mechanical and Civil Engineering Department. In the Electrical Engineering Department, the demand for accommodation for research work could not be fully met. For researches in chemistry two Ph.D. and one M.Sc. were awarded by the University of London. Fifty-four other degrees of the University of London and thirty-four National Certificates in Engineering were obtained in addition to many other examination successes. An enumeration of positions obtained by Polytechnic students during the past thirteen years includes 1,218 domestic science inspectors, teachers, organizers and practitioners, 413 engineers, 413 health visitors, sanitary inspectors, nurses, etc., 233 chemists and 97 art practitioners. The general recognition of the enormous national importance of sound teaching in domestic science may be expected to lead to increased activity in this department of the Polytechnic.

\section{The Plant Hormone Committee}

As the outcome of a meeting held at the Royal Botanic Gardens, Kew, on November 6 (see Nature, 141,88 ; 1938), a Committee, to be known as "The 